\title{
The Manifestation of Multiculturalism in the Works of Maalouf's "In the Name of Identity" and E. M. Forster's "A Passage to India"
}

\author{
Mohammed AL-Badawi ${ }^{1}$
}

\author{
Alaeddin Sadeq ${ }^{2}$
}

${ }^{1}$ Assistant Professor, Department of English Language \& Literature, Zarqa University Jordan, P.O.Box:132222-Zarqa-13132-Jordan; mbadawi@zu.edu.jo

${ }^{2}$ Associate Professor, Department of English Language \& Literature, Zarqa University Jordan, P.O.Box:132222-Zarqa-13132-Jordan; alaeddin_english@zu.edu.jo

\section{Doi:10.5901/mjss.2016.v7n2s1p251}

\section{Abstract}

This paper probes the claims regarding the success or failure of multiculturalism in Amin Maalouf's In the Name of Identity and E. M. Forster's A Passage to India. The researchers hypothesize that the applicability of multiculturalism is very much dependent on the political situation of the society in question. More precisely, it depends on whether or not that society has experienced the subjugation of colonialism. Examples from both texts will be critically reviewed in light of multiculturalism, postcolonialism and the post-colonial notion of hybridity. Each of these texts concerns a distinct political situation, the one having to do with life under colonial authority (A Passage to India), while the other is written in a politically free country (In the Name of Identity). The selected examples from both texts show that multiculturalism failed in the colonized society, leading to tension and a clash between the two cultures, whilst achieving relative success in the societies of the colonizers, thus resulting in hybridity. Therefore, it is concluded that multiculturalism might have relative chances of success insofar as it is not enforced or imposed on people.

Keywords: Multiculturalism, Postcolonialism, Hybridity.

\section{Introduction}

Multiculturalism is a wide ranging concept that has been tackled from many perspectives throughout the past years. In basic terms, as claimed by Lea (2004), there are two kinds of multiculturalism: the first kind looks at multiculturalism as celebrating each culture's individuality and right to existence, without there having to be any necessary connection between them, while the second type equates multiculturalism with cultural diversity, meaning that people can coexist happily through an acceptance of the other that goes beyond mere tolerance. The latter is of our particular interest in this study. Specifically, the present researchers are interested in whether acceptance of the other can actually exist on real grounds, and if so, what those grounds might be and whether they change from time to time and place to place. Understanding multiculturalism represents the right of each culture to exist; migrants living in the West have shed light on multicultural phenomena. Edward Said (1978) was clearly against the notion of multiculturalism in the colonized society, because he could see the way colonized people were 'othered', disrespected, marginalized and considered inferior. Others, like Naomi Nye (1997), support the idea of multiculturalism insofar as it is viewed as a chance for peaceful and cooperative coexistence between colonizers and colonized. Nye demonstrated this in her work Habibi, where, Liyana, a Palestinian-American girl, falls in love with the Jewish boy Omer. The girl contends against her family's alleged unprejudiced beliefs, reminding her father of his own words: "Does it make sense that any God would choose some people and leave the others out?... God's bigger than that!", thus proving, long after the last page is turned, why Arabs, Jews, and all people can no longer live in harmony the way they once did. The main objective of this study is to explore the chances of success of multiculturalism as a theory in E.M. Forester's A Passage to India (1924), and Amin Maalouf's In the Name of Identity which was published in French in (1996) and was translated into English in (2000).

This study will begin with a brief introduction of the concepts of multiculturalism and postcolonialism, and the interrelation between them. It further proceeds to discuss the issue of hybridity, understood as the crowning achievement of a successful multicultural society. Two texts will be analyzed in light of these three concepts. The present researchers chose these concepts as they are thought to contribute to a better understanding of a multicultural society. Moreover, Maalouf's view in In the Name of Identity draws on his own experience as Lebanese national who migrated to France, the 
land of his colonizers. E. M. Forster's A Passage to India, on the other hand, tells a story of people who witnessed and experienced first-hand life under British colonialism.

\section{Theoretical Framework}

\subsection{Multiculturalism}

Multiculturalism is a concept that has been defined by many philosophers and critics differently, and tackled from many viewpoints, i.e., culturally, politically, philosophically, religiously -- even sexually. Song (2014) asserts that multiculturalism is a body of thought in political philosophy which has become the umbrella term to characterize the moral and political claims of a wide range of disadvantaged groups -- it is a response to cultural and religious diversity. Most theorists of multiculturalism tend to focus their arguments on immigrants who belong to ethnic and religious minorities, minority nationalities, as well as indigenous peoples, which eventually become minorities in their own lands on account of colonial subjugation.

In short, multiculturalism is often regarded as a cultural issue, at the expense of factors such as religion, language, ethnicity, nationality, and race being overlooked, while culture itself is to be understood in a broader sense as a term that includes the above mentioned factors within it. Al-Khatib (2009:13) defines multiculturalism as "an applied ideology of racial, cultural and ethnic diversity within the demographics of a specified place," arguing that, in this sense, it implies that no culture is perfect or can be taken as universally valid; that, on the contrary, all cultures should be open to and benefit from each other, since multiculturalism deals with people from various backgrounds living in the same society. Similarly, Charles (1994) (cited in Al-Khatib, 2009) stresses that multicultural literature should support pluralism and celebrate diversity.

Moreover, identity is also often discussed within multiculturalism. Judith Martin and Thomas Nakayama (1999) (cited in Al-Khatib, 2009, p.17) defined multiculturalism as "an identity based on two or more cultural frames of reference". This is supported by the fact that multicultural literature started with immigrants in the United States who played a key role in its appearance and development in America, such as Edward Said and Werner Sollers (ibid.).

Regarding the meaning of culture, Wilfred, et al., (2005) question whether it is best to celebrate 'the other' or to focus on the difference instead. In this context, we can't conceive each culture isolated, i.e., as being separate from other cultures, if we choose to accept the definition put forth by Leitch (2001:26): "The aggregate of language, knowledge, belief, morality, law, custom, and art collectively acquired by human beings". Culture, in that sense, is what shapes and forms our beliefs, attitudes, expectations and behaviour, i.e., all that underlies our social practices and what we consider to be 'normal'. (Haddock and Sutch, 2005). Leitch's conception of culture, then, allows us to overcome the dichotomy presented above in that it may be understood as a form of unity-in-plurality. In other words, it makes it possible, without obviating plurality, to create a common cultural platform that will beget understanding and even a common identity.

Simon Laden and David Owen (2007) raised the issue of whether multiculturalism suffices, by itself, to counteract the dangers of racism, or whether this requires the presence of additional factors. If we take into consideration the social sphere and the ethno-racial dynamics of the societies which we are here concerned with, then the question may be presented as follows: can people of different races live peacefully together once existing together, or is this dependent upon additional factors as well?

In this scope, Blum (1992) (cited in Song, 2014) establishes distinctions between antiracism, on the one hand, and victimization and resistance, on the other, as well as between multiculturalism, and cultural life, cultural expression, achievements, and the like. As such, the notion of antiracism should normally be restricted to societies where groups of people are being victimized according to their race, while multiculturalism refers to societies in which peaceful coexistence could be achieved in spite of their diversity.

Clyne and Jupp (2011) argued that the main problem when discussing such a wide-ranging concept as multiculturalism lies in the variety of meanings it carries within it, in the sense that it is a contested term whose meaning, much like other terms (technical and otherwise), varies according to the individual it is used by and the context it is used in. They argue, furthermore, that multiculturalism often fails due to political timidity, i.e., inaction, and conservatism. Similarly, Song (2014) suggests that the greatest challenges faced by multiculturalism are mostly political, rather than philosophical, as evident in the backlashes against migrants that have become common place in the West since the beginning of the twenty-first century. In this context, multiculturalism has been discussed mostly by migrants and postcolonials, in an effort to define themselves and find their place in a post-colonial world.

In line with these issues, the coming section will give a brief account of the basic assumptions of postcolonialism, and the way they relate to multiculturalism and hybridity. 


\subsection{Postcolonialism}

Some philosophers and theorists viewed multiculturalism from a postcolonial perspective. For example, Al-Khatib (2009, p.13) defined postcolonialism as the interrelations between "all cultures affected by colonial rule from the moment of colonization to the present day". Postcolonialism as a theory discusses a number of issues pertaining to immigration, slavery, suppression, resistance, representation, race, gender, place and responses to the pervasive master discourse and worldview of imperial Europe (ibid.), i.e., eurocentrism.

Tyson (2006) asserts that postcolonial theory offers us a framework for examining the similarities among all critical theories that deal with human oppression. Previously colonized peoples mostly suffer from a negative self-image resulting from the devaluation, and even prohibition, of their cultures during the colonial period, where the colonizers, placing themselves at the center of affairs, forced the colonized into the periphery of society, along with the indigenous cultures, thus marginalizing their identity. In many such cases, the colonizer came to be idealized - his culture understood by the colonized as superior or even universally valid. This kind of treatment, which generates the feeling of inferiority among the colonized, would eventually beget one of two possible reactions: either mimicry, by the colonized, of the invasive culture, or the utter, at times violent, rejection of the colonialist ideology. The first phenomenon mirrors the yearning of the colonized to be accepted, as well as a feeling of shame towards their own culture. The second response is often the result of falling back upon and embracing one's culture and language at the expense of the colonizer's, whilst, in a sense, grieving for the vast portions of it that are oftentimes lost over generations of colonialism. The feeling of diaspora and of being caught between cultures, whilst, in a sense, belonging to neither, pushes the ex-colonials to assert a native culture as a way of (re)building a self-image and avoiding being swamped by the invasive culture. It would, however, be mistaken to view the effects of colonialism as a one way street, seeing as the colonizers' cultures are also permeable to influence by their indigenous, pre-colonial counterparts.

Al-Khatib (2009) argues that all ethnic groups in America suffer the same problems of isolation, alienation and cultural oppression, which caused them to become, in one way or another, invisible or forgotten. As a result of this, multicultural literature emerged to embody the cultures, races and histories of the groups it portrays. This is why it's common for postcolonial writers to be exiled from their countries for producing their literature. The issue of location is a key theme, insofar as place generates mixed feelings of belonging. Once unable to fully appreciate or understand the place one came from, feelings will arise of being both an outsider and an alien in one's own land.

Furthermore, the interaction between majority and minority group members can be sometimes negative; taking the form of conflict, or it can be fruitful, taking the form of acceptance and, over time, assimilation, accommodation and acculturation. Postcolonial writers have been preoccupied with issues of hybridity, creolization and diaspora; with the mobility and crossovers of ideas and identities made possible by colonialism (Tyson, 2006). Loomba (1998) sees hybridization as a concept that challenges and undermines postcolonialism (cited in Al-Khatib, 2009). Al-Khatib (2009, p.3) also shares this view, conceiving hybridity as "the acceptance of diversity beyond the traditional colonial-colonized divide". Let us, then, turn our attention to the concept of hybridity so as to discern its meaning and implications in greater detail.

\subsection{Hybridity}

Adams (1971) denies that hybridization is a marginal phenomenon, whilst asserting, on the contrary, that it is the terrain in which contemporary political identities are constructed. Al-Khatib (2009, p.14) defined hybridity as "the creation of new transcultural forms within the contact zone produced by colonization". Bhabha (cited in Al-Khatib, 2009, p.4), on the other hand, suggests that it is "an ambivalent and contradictory space in which the colonizer and colonized interrelate, deconstructing - and then reconstructing - subjectivities and cultural systems". For Bakhtin (1981, p.385) (cited in AlKhatib, 2009, p.18), hybridization is "a mixture of two social languages within the limits of a single utterance, between two different linguistic consciousnesses, separated from one another by an epoch, by social differentiation or by some other factor". Leitch (2001) thought of hybridity as a way to conceptualize an international culture, it is the cutting-edge of translation, negotiation, dialogic, in-between, cross-reference and ambivalence - the space that carries the meaning of culture.

While Said and Spivak, cited in Leitch (2001), saw the West and the East through the lens of post-colonial dichotomies - the center and the periphery, the colonizer and the colonized, the oppressor and the oppressed, the self and the other - Bhabha deconstructed those binary oppositions to reach the third zone which is hybridity, proposing that nationalities, ethnicities, and identities are dialogic and indeterminate (Leitch, 2001). Bhabha's interest was in the interaction going both ways between the two spheres of colonizers and colonized, shifting his focus from 'the noisy 
command of colonial authority' and 'the silent repression of native traditions' to 'the colonial hybrid'. His positive views of hybridity made us more aware of the situation within colonial and postcolonial societies (Bertens, 2007).

Tyson (2006) asserts that this hybridity, or syncretism, as it is sometimes called, does not consist of a stalemate between two warring cultures, but is rather a productive, exciting, positive force in a shrinking world that is itself becoming more and more culturally hybrid. This view encourages people who have been subject to colonization to embrace the multiple and often conflicting aspects of the blended culture that is theirs and that is an indelible fact of history. This hybridity is viewed as a point of strength, since the transaction is a two-way process, giving the hybrid an identity shaped jointly by two cultures, challenging the binary oppositions and erasing the established boundaries (Al-Khatib, 2009).

In the following section, the selected works will be analyzed in light of the concepts that have been discussed above in an attempt to see how multiculturalism operates, firstly in a society that was subject to colonization, and secondly in a society which, having once well illustrated the role of an oppressive colonizer, came to be considered, in the present time, as a society that relatively embraces migrants from all over the world.

\section{The Discussion of "In the Name of Identity"}

Maalouf's main concern in this work is with the reason why "so many people commit crimes nowadays in the name of religious, ethnic, national" and other types of identity. His work is rich with examples and case studies, many of them legitimized by personal experience. Maalouf's masterpiece is a stimulating plea for more balanced attitudes towards the collages of identities that define us. A person's identity is the whole set of elements which, on the one hand, links him or her to all others who share them, and, on the other hand, when taken together, single them out and distinguish them from all other people. The author himself is a good example of this 'paradox' of identity. Maalouf is of Lebanese origin, but migrated to France, where he now lives as a successful novelist. He is also an Arab, and comes from a Christian family. Any of these properties, taken singly, links him to huge portions of mankind. Taken together, however, they make him the member of an utter minority. In addition, he writes his novels in a language (French) that is not his mother tongue - a practice which is typical among migrants.

Maalouf argues that we are all bound to have multiple identities, due to cultural, economic, social and political globalization; we are acquainted with more cultures than ever before and as such must learn to cope with the confrontations that necessarily arise from that predicament. We should accommodate for all of our many allegiances and all the diverse cultural backgrounds we are connected to: identities should be rich and colorful. But this claim, according to Maalouf, is threatened by two interconnected reasons. The first is the fact that identities can be harmed by oppression or discrimination. The second is the ideology of exclusive identities - the claim that a certain allegiance excludes the allegiance to other groups. If a group is being discriminated against, its members will react by stressing this twist of their identity: they will put their membership to the discriminated group first in their hierarchy of allegiances, in a sense relinquishing all others, settling for a monopolized identity - an identity which is no longer rich and balanced, but dominated by a single allegiance. Such are the "murderous or mortal identities", the "identities that kill"; that lead to the state of mind that results in crimes of identity. This is "how murderers are made - it's a recipe for massacres".

This notion of multiple identities (hybridity) is referred to in the following quote. Amin Ma'louf (1996, p.44) asserts:

Say to the one party: "The more you steep yourself in the culture of the host country the more you will be able to steep yourself in your own"; and then, to the other party: "The more an immigrant feels that his own culture is respected, the more open he will be to the culture of the host country."

This excerpt clarifies the main factor behind the success of multiculturalism, which is respect. If the immigrant feels the respect of the host country towards his beliefs and culture, he will embrace that new culture, and will be more apt to let in, and even absorb it. This will result in taking the best of the two cultures, which is to say, hybridity. Maalouf continues by saying that, if a group of people feels threatened by the other, it will more likely become hostile towards that other and less approachable, which is very natural, self-defensive reaction. So, they will act accordingly. This alludes to the political status of the society we are examining, and to what extent it affects the success or failure of multiculturalism in that particular society.

One must bear in mind, when analyzing Maalouf's writings and the like, that these are people who migrated willfully to the lands of colonizers, accepting the culture of the country they themselves chose to be part of. It is totally different when one chooses the place one lives in, along with its respective culture, rather than being forced to live under the control of certain people, to adapt to their culture and perhaps live as a third class citizen in one's own land, as is the case in colonized countries. This is why many immigrants, whether ex-colonials or not, seem to accept the idea of multiculturalism more openly. It is, on the other hand, understandable that the colonized might tend to reject it, since the other is perceived to threaten their lives; to despise their culture and religion. 
Maalouf contends, regarding the issue of coexistence between peoples of different races, religions, cultures, etc., that its success is dependent upon many factors to succeed - mainly, respect and acceptance. He states in his novel:

"When someone feels that his language is despised, his religion ridiculed and his culture disparaged, he is likely to react by flaunting the signs of his difference. When someone feels he has a place in the country where he has chosen to live, then he will behave in quite another manner." (Maalouf, 1996, p.43)

Living in a country that is free from occupation and its consequences, people normally welcome multiculturalism, because diversity here will mean plentitude. Meanwhile, in colonized countries, this diversity would carry aggression and hostility within its ties. Thus, it would be violently rejected.

Another major issue discussed within this novel is identity, and whether a single quality in one's personality defines one to the detriment of other aspects. Can a person be judged solely according to his or her nationality, religion or color? If a Christian purposefully kills another man, should this be taken to imply that all Christians are killers and heartless? The answer, of course, is "no". It shouldn't. One's identity is shaped from many angles through the passing of the years; it is not static. To return to the aforementioned example, if we take two Christian men, where one is a doctor and the other is uneducated, there is no question that their way of thinking will be quite different, on account of the profound differences in the experiences they have been through. This calls for the reader to differentiate between ethnicity and identity, and take into account how each person in any given ethnic group carries a different identity depending upon his personal experiences, preferences; his origins, religious beliefs, and even his self- and public images, etc. This is related to our discussion in the way that one must look at groups of peoples and ethnicities: if multiculturalism is to achieve success in any society, attention must be given to individual rights, in a way that treats people equally instead of generalizing and making pre-judgments and stereotypes about each group. And as has been made evident throughout history and literature, if a country is under colonial authority, equality and justice will necessarily withdraw, since colonialism itself means the stealing of other peoples' lands, and triumph of some over others. Multiculturalism can work if the two parties are welcoming of the notion, in a peaceful political manner. This may pave the way for different cultures to live in harmony, exchanging and taking the best in each culture openly, without being forced and, most importantly, without having bad self-images resulting from one's feeling of betrayal towards his own culture.

If we view identity the way Maalouf does rather than as the typical conflict between the self and the other, one can actually see how, as Maalouf states,

"There are people on "our" side with whom - one - will ultimately have little in common, while on "their" side there are some to whom - one - might feel very close." (Maalouf, 1996, p.31)

This is exactly what happened between Aziz and Fielding from the coming discussion of $A$ Passage to India; but their friendship couldn't survive because of the political status the country suffered from and the tyranny of occupation. This is clearly justified - when the other represents a threat to the self, then one can be led to the worst kind of extremities. On the other hand, this view is what helped Maalouf accept his hybrid identity.

In this work, it can be concluded that multiculturalism has a chance of survival on real grounds, depending mostly on the political status of the society it is found in, as well as the level of acceptance of one another and, most importantly, respect of the other's culture, religion, language, etc. This has a good chance of success in a society that is not under the subjugation of colonial power. The following section will lens multiculturalism in a colonized society, taking as an example E.M. Forster's A Passage to India.

\section{The Discussion of "A Passage to India"}

A Passage to India gives a good example of the clash of cultures between the East and the West based on social, political and religious backgrounds. The clash of imperialist westerners with the native Indians, as well as between Hindus and Moslems, are all recurring themes in the novel. A group of Moslem Indians discuss the possibility of befriending an Englishman. This Englishman comes to India with every intention of behaving like a gentleman. This portrayal is a reinforcement of the superiority of the colonizers and an embodiment of eurocentrism. The central incident in the novel, Adela's accusation against Aziz and Aziz's trial, reveals the inevitability of antagonism as long as there is colonization. At the end of the novel, a very important line that can be seen as evidence of this argument: "No, not yet (...) No, not there". (Forster, 2002, p.298)

The friendship between Aziz and Fielding wasn't impossible, seeing as they had in fact taken a liking to one another. The problem was in the timing (yet) and the place (there). But what does this mean? It simply means that only 
when the occupier leaves the land of the occupied and gives it back to its people, only then can friendship become a reality between the two parties. Otherwise, as long as the two sides are warring, the meaning of friendship would forever be undermined by an underlying feeling of superiority in the colonizer's mind, and of subordination, submission, and yielding, in that of the colonized. This is why Aziz and Fielding's friendship can't happen but outside India.

Yousef $(2010$, p. 35$)$ argues that:

"Forster's novel is great because it can apply to all times. What we humans need to do in order to stop hatred, racism, violence, and most importantly wars and political conflicts is this: open our minds and hearts to each other. It is that simple. We only need to accept each other, no matter how different we look, talk, and behave. Beauty lies in variety, and this is what is beautiful about our world."

But is this really the case? In the novel we see how Aziz and Fielding both open their hearts and minds to each other, but tragically their friendship failed to develop further. Towards the end of the novel Fielding says: "Why can't we be friends now? (...) It's what I want. It's what you want." (Forster, 2002, p.298). It is left clear that they both wanted this friendship to continue. But things were out of their hands; they both played certain roles they couldn't escape - one is a colonizer and the other is a colonized. That's why their friendship was wrecked.

In the novel Fielding was regarded as different from other Englishmen by Forster, who describes him as follows (p.32, 33):

"The world, he believed, is a globe of men who are trying to reach one another and can best do so by the help of good will plus culture and intelligence - a creed ill-suited to Chandrapore, but he had come out too late to lose it. He had no racial feeling - not because he was superior to his brother civilians, but because he had matured in a different atmosphere, where the herd instinct does not flourish."

In this description it shows that Fielding didn't carry presumptions and prejudgments about India or its people in his mind. The way his mind worked was more open and free from the poison any other occupier usually carries within his thoughts. On the contrary, Fielding didn't consider Indians as "the other". Nonetheless, he was still an occupier. Maybe it's what Forster wanted us to think, since Fielding was a representation of him. Looking at the novel closely, the way it was written, the language used to describe the land, its people, and its weather, one must notice the colonialist ideology behind the words used. India and its people were intentionally degraded, while Englishmen were given the superior qualities associated with sanity and civilization. This is evident from the very beginning of Chapter One, as the author describes the Indian city, Chandrapore: "Except for the Marabar Caves - and they are twenty miles off - the city of Chandrapore presents nothing extraordinary." (Forster, 2002, p.1) Forster continues to describe the weather and the city as dull and ineffective, giving the reader a boring and dull atmosphere while reading. Bakhtin, as cited in Salman (2010), maintains that the content of dialogue and the discourse of characters throughout the novel is determined by the ideology of the author. It is nearly impossible to separate literature and culture from politics (cited in Jajja, 2013, p.38). Said (1993) likewise states that literature can't be politically innocent. It is a typical way of a colonialist to degrade the colonized and treat them as stereotypes or, what is more distressing, as less than humans. This, after all, is the most effective way to make the colonized doubt themselves and turn to the colonizer's way of living; to embrace his culture, worldview, and everything else, only to be accepted and to avoid being laughed at or considered backward. This method usually paves the way for colonizers to take control easily, while the colonized come to believe that they're inferior and need to be led or controlled by others, by those white Englishmen who gave themselves the quality of superiority, pretending that they have a mission to protect others from their savage way of living, all the while merely taking for themselves what once belonged to others. Jajja (2013) maintains that the way Forster dealt with India and Indians in the novel, and the way it was written, clearly portray the ideology and mentality of a colonialist, noting the way he depicts the Indian characters as unorganized, as having untidy houses, as not caring for their appearances, and not being punctual, while claiming the opposite for the British. This is clearly a colonialist ideology, giving his British characters the center while casting the Indian ones into a somber, barbaric periphery.

Furthermore, we can clearly see how colonialism and imperialism affected the two parties, the colonizer and the colonized. Aziz being a colonized person who seeks to befriend the colonizers reflects submissiveness, whereas, as Memmi (cited in Rawashdeh, 2008) argues, "the colonizer who is content with this role has to maintain the pretense that the colonized are inferior and subhuman in every respect". One needs to look no farther than Ronny for an example of this. But when looking at Fielding, the colonizer who is taking the role of a humanist, refusing to play the part of the cruel colonizer, this results in losing bits of his identity and becoming overwhelmed with guilt - a guilt which stems from his original identity, a British colonizer in India. If he wants to shed his feelings of guilt, then he must leave the colony. But 
there's a slight difference between the colonizer and the colonized here. While the colonized has to accept his role, and is left with no other options, the colonizer is free to accept or neglect his role as a colonizer by either staying, or returning to his homeland.

Rawashdeh (2008) further claims that the reasons behind the tension between Indians and the English is the result of different religions, languages, cultures, traditions, different ways of life and lack of understanding towards the other. On the other hand, we can clearly notice that these same differences are found in other countries but might result in hybridity and harmonious relationships due to the stable political circumstances instead of the tension of colonialism, as in Maalouf's novel.

In A Passage to India, we can see how the Indian characters suffer from the effect of colonialism; whether it is in their being ashamed of their own culture and of themselves, or in their striving to be accepted by behaving and dressing like the English. It is as if hybridity has been forced upon them; they had to change quickly, to adapt in order to survive in the world that shifting and changing dramatically around them. Nonetheless, they didn't become English, and still they were rejected, and worse yet, considered mimics by the English. As such, they were trapped between two cultures, struggling to assimilate one or both, whilst belonged to neither. We can come to the conclusion that multiculturalism fails in A Passage to India, mainly because it was built with power instead of respect, on coercion instead of acceptance, as illustrated by the superiority that the English claimed over their Indian counterparts. This kind of relationship can never result in assimilation; on the contrary, it makes the other more hostile and is liable to produce nothing but violence and long-lasting hatred.

To conceive of the hybridity and mimicry that became a part of Indian society, as seen throughout the novel, as multiculturalism, would be nothing short of misguided. In fact, multiculturalism, if it is to be fruitful, can never be based upon anything other than the utmost respect and acceptance of the other, which alone pave the way for dialogue and cooperation.

\section{Conclusion}

Multiculturalism as a concept should be understood as something that blends cultures and societies together to bring out the best in each. Whereas some writers thought it could be applicable to all societies, in any place in the world where two parties or more are welcoming of the idea itself, this study has shown how other conditions must be satisfied in order for its true meaning to manifest itself. The main hypothesis which we set out with was that multiculturalism wasn't likely to work out in the lands of the colonized in the colonial period, whereas it might in the postcolonial time. The texts chosen to illustrate this particular point were "In the Name of Identity" which is a postcolonial novel, and "A Passage to India" which is a colonial one. The assumptions made earlier in this study are, by means of this analysis, reinforced. Relatively speaking, multiculturalism may work in any society, as long as that society is free from the scourge of colonialism and colonialist ideologies, and is supported by mutual respect and a wish to strengthen ties, instead of harboring division. It cannot - it will not - be fruitful between warring parties, as in the colonial period, where the lands of some are swindled by those who claim themselves superior, and exert the type of condescending and power-based authority upon their peers that can only destroy relationships - not build them.

\section{Acknowledgement}

This research is funded by the Deanship of Scientific Research at Zarqa University.

\section{References}

Adams, H. (ed.) (1971). Critical Theory since Plato. New York: Harcourt Brace Jovanovich.

Al-Khatib, Y.W. (2009). An Examination of Postcolonialism, Multiculturalism and Hybridity in Naomi Shihab Nye's Sitti's Secrets, Habibi, 19 Varieties of Gazelle Poems of the Middle East and Red Suitcase. (M.A Thesis). Retrieved from the center of Thesis Deposit in the Library of University of Jordan.

Bertens, H. (2007). Literary Theory, the Basics. (2ND edition). London and NY: Taylor and Francis group

Clyne, M. and Jupp, J. (eds). (2011). Multiculturalism and Integration, a Harmonious Relationship. Australia: ANU E Press, The Australian National University

Forster, E.M. (2002). A Passage to India. Lebanon: York Classics. York Press.

Guerin, W.L., Labor, E. , Morgan. L. Reesman, J.C., Willingham, J.R. (2005) A Handbook of Critical Approaches to Literature. (5 Edition). NY: Oxford University Press.

Haddock, B. and Sutch, P. (eds). (2005). Multiculturalism, Identity and Rights. Published in the Taylor and Francis e-Library. 
Jajja, M. A. (2013) A Passage to India: The Colonial Discourse and the Representation of India and Indians as Stereotype. Gomal University Journal of Research, 29(1). June.

Laden, S. and Owen, D. (eds) (2007). Multiculturalism and Political Theory. NY: Cambridge University Press.

Lea, R. (2004). Interviews by Cindi John. BBC News. UK. (18/612014) Retrieved from: <http://news.bbc.co.uk/2/hi/ uk_news/3600791. stm>.

Leitch, V.B. (ed). (2001). The N'prlon Anthology Of Theory and Criticism. NY: University of Oklahoma, by W. W. Norton \& Company, Inc. Maalouf, A. (1996) translated into English by Barbara Bray (2000). In the Name Of Identity. (1 ${ }^{\text {st }}$ Edition). U.S.A., NY: Penguin Books.

Nye, N. (1997). Habibi. NY: Simon and Schuster Children's Publishing Division.

Rawashdeh, A.A. (2008). The Tension of the Social Relations between the Colonizer and the Colonized Under the Impact of the British Colonialism to India in Forster's A Passage to India. MA Thesis. University of Jordan, Center of thesis deposit. Amman: Jordan.

Said, E. (1978). Orientalism. (1 ${ }^{\text {st }}$ Edition). NY: Vintage Books, A Division of Random House Ltd.

Salman, D.F. (2010). The Dialogue of Conflicting Ideologies: A Critical Study of Forster's A Passage to India and Conrad's Nostrom Through Bakhtin's Dialogics. MA Thesis. The University of Jordan, Center of Thesis Deposit. Amman: Jordan.

Song, S. "Multiculturalism". The Stanford Encyclopedia of Philosophy. (Spring Edition, 2014). Edward N. Zalta (ed.). (5th May, 2014). Retrieved from: <http://plato.stanford.edu/archives/spr2014/entries/multiculturalism/>.

Tyson, L. (2006). Critical Theory Today. NY, London: Routledge Taylor \& Francis Group.

Yousef, R.H. (2010). Friendship in A Colonial Context: Forster's A Passage to India and Kipling's Kim. MA Thesis. University of Jordan, Center of thesis deposit. Amman: Jordan. 